\title{
Złożoność biochemiczna. Emergencja czy projekt? ${ }^{*}$
}

W Darwin's Black Box: The Biochemical Challenge to Evolution [Czarna skrzynka Darwina: biochemiczne wyzwanie dla ewolucjonizmu] Michael J. Behe, posługując się współczesnymi kategoriami biochemii, wskrzesił argument Williama Paleya głoszący, że pośród organizmów żywych występuje nieredukowalna funkcjonalna złożoność, która sugeruje działanie projektanta-stwórcy. ${ }^{1}$ Ponownie przypomniał on wyzwanie Paleya dla naukowców, by zaoferowali naturalistyczne wyjaśnienie, które solidnie tłumaczyłoby taką złożoność i adaptację. Darwin odpowiadał na to wyzwanie sugerując, że mechanizm doboru naturalnego, działający na przypadkową, dziedziczną zmienność, może wyjaśnić biologiczną adaptację i dziedziczenie z modyfikacją. Behe argumentuje jednak, że Darwin nie mógł wiedzieć tego, co wiemy obecnie o organizmach $\mathrm{i}$ ich rodowodach na poziomie biochemicznym i molekularnym. Owa wiedza, twierdzi, wykracza poza granice mocy eksplanacyjnej koncepcji darwinowskich, pozostawiając nam jedynie alternatywę inteligentnego projektu w wyjaśnieniu

*Bruce H. Weber, „Biochemical Complexity: Emergence or Design?”, w: John Angus Campbell and Stephen C. Meyer (eds.), Darwinism, Design and Public Education, Michigan State University Press, East Lansing 2003, s. 455-462. Z języka angielskiego za zgodą Autora przełożył Dariusz Sagan. Recenzent: Grzegorz NowaK, Zakład Biochemii UMCS, Lublin.

${ }^{1}$ M.J. Behe, Darwin's Black Box: The Biochemical Challenge to Evolution, The Free Press, New York 1996. 
emergencji nowych i złożonych struktur oraz zjawisk zachodzących w systemach żywych.

Zamierzam rozważyć, czy złożoność biochemiczna, tak jak przedstawia ją Behe, rzeczywiście jest nieredukowalna - a jej emergencja wymyka się analizie naukowej. Behe nie zaprzecza, że dobór naturalny może oddziaływać na populacje, powodując zmiany w częstościach występowania genu. Nie zaprzecza również występowaniu mutacji. Uznaje on fakt, że mutacje w białkowych sekwencjach aminokwasów świadczą o dziedziczeniu z modyfikacją. Do tego stopnia zgadza się on z poglądem, że biochemia popiera istnienie zmiany ewolucyjnej.

Jednakże systemy białek i enzymów, wykonujących poszczególne czynności biologiczne, jak wić bakteryjna, transdukcja sygnałów przez błony, transport przez błony i w obrębie komórek, krzepnięcie krwi, układ immunologiczny oraz powstawanie i regulacja metabolizmu, Behe postrzega jako złożone ze zbyt wielu składników, które musiałyby precyzyjnie ze sobą oddziaływać, by wyewoluowały $\mathrm{w}$ chaotycznym, stopniowym procesie doboru naturalnego. Nie chodzi o to, że pierwotne oko czy wić mogły nie zyskać przewagi selekcyjnej, ale raczej o to, że otrzymanie nawet tak prymitywnych struktur wymagałoby wielu zmian molekularnych, nie posiadających żadnej wartości funkcjonalnej, zanim wszystkie konieczne składniki molekularne nie byłyby obecne. Dlatego przytaczane przez Behe’ego złożone układy biochemiczne nie mogłyby powstać inaczej niż na podstawie projektu - tak samo jak w przypadku pułapki na myszy, której Behe używa jako analogii zastępującej zegar Paleya. $Z$ założenia odrzuca on jakiekolwiek inne alternatywy. Daje do zrozumienia, że współcześni ewolucjoniści w celu obrony paradygmatu darwinowskiego ową nieredukowalną złożoność albo ignorują, albo wyjaśniają przy pomocy „takich sobie bajeczek”.

Behe często wspiera się domniemanym faktem braku podejmowania przez biologów ewolucyjnych prób dostarczenia wiarygodnych wyjaśnień przyczynowych emergencji takich złożonych układów adaptacyjnych. Nie uznaje też pracy rzeczywiście wykonanej przez dar- 
winowską wspólnotę badawczą. Ignoruje on właściwie cały obszar obecnych badań nad samoorganizacją, nad zjawiskiem emergencji.

Udzielono licznych odpowiedzi Behe'emu - mieli w tym udział również biochemicy, łącznie ze mną - które odnosiły się do tego, jak naprawdę powinien on przedstawić obecny stan literatury przy uwzględnieniu podanych przez niego konkretnych przykładów. ${ }^{2} \mathrm{~W}$ rzeczywistości opublikowano próby wyjaśnienia zagadnień, takich jak powstanie wici, układu krzepnięcia krwi czy biochemicznej podstawy procesu widzenia. Należy przyznać, że przedstawienie tego, w jaki sposób aktualne dane biologii molekularnej sugerują procesy duplikacji genu, tasowania domen i eksonów oraz ewolucji dywergentnej nie wyjaśnia, jak niekompletne systemy zyskują przewagę selekcyjną. Obecnie jesteśmy jednak na etapie gromadzenia wystarczającej ilości danych na podstawie sekwencji DNA i trójwymiarowych struktur białek, by w niedalekiej przyszłości przeprowadzać liczne testy przypuszczalnych wyjaśnień ewolucyjnych, co do których można by się spodziewać, że nie będą „takimi sobie bajeczkami”.

Behe argumentuje na przykład, że wyjaśnienie pochodzenia układu immunologicznego znajduje się poza zasięgiem darwinizmu z powodu ogromnej złożoności tego systemu i dużej liczby genów potrzebnych do jego utworzenia. Jednakże ostatnio ujawnione odkrycie funkcji transpozaz RAG i transpozonów w układach immunologicznych $\mathrm{u}$ współcześnie żyjących kręgowców oraz możliwego wpływu, jaki mogło mieć wprowadzenie takiej aktywności na emergencję układu immunologicznego u kręgowców, ukazuje ryzykowność założenia, że ewolucjonizm nie potrafi wyjaśnić złożoności jakiegokolwiek systemu. ${ }^{3}$ Można już utworzyć program badawczy, który dzięki analizom sekwencji i symulacjom komputerowym zbada przypuszczalne drogi

\footnotetext{
${ }^{2}$ B.H. Weber, „Irreducible Complexity and the Problem of Biochemical Emergence”, $B i$ ology and Philosophy 1999, vol. 14, no. 4, s. 593-605.

${ }^{3}$ A. Argawal, Q.M. Eastman and D.G. Schatz, „Transposition Mediated by RAG1 and RAG2 and Its Implications for the Evolution of the Immune System”, Nature 1998, vol. 394, s. 744-751.
} 
emergencji układu immunologicznego, a tym samym złożoność kręgowców, które nie mogłyby istnieć bez własnego systemu odpornościowego. Gdyby teoria inteligentnego projektu była panującym paradygmatem, badania zatrzymałyby się na wyznaczeniu funkcji owych transpozonów czy transpozaz.

Jeśli chodzi o pochodzenie, czy właściwiej - emergencję życia, Behe powiada, że faktycznie niewiele zrobiono $w$ celu jego wyjaśnienia i że podejmowano nieadekwatne próby dostarczenia takich wyjaśnień. Behe opiera się głównie na wynikach komputerowego przeszukiwania tytułów artykułów opublikowanych w Journal of Molecular Evolution argumentując, że biologowie ewolucyjni nie wysilili się zbytnio, by rozwiązać ten problem. Pojawiają się tutaj dwie trudności.

Po pierwsze, tytuły artykułów nie są dobrym wyznacznikiem treści. W Journal of Molecular Evolution opublikowano rozprawy na temat pochodzenia życia, które umknęły poszukiwaniom Behe'ego, ponieważ nie mają w tytule słowa pochodzenie. Przykład może stanowić rozprawa na temat roli struktur błonopodobnych i gradientów termodynamicznych $\mathrm{w}$ powstawaniu protokomórek. ${ }^{4}$

Po drugie, większa część literatury na temat pochodzenia życia nie została opublikowana w Journal of Molecular Evolution, lecz w takich czasopismach jak Origins of Life and Evolution of the Biosphere, BioSystems, Journal of Theoretical Biology czy Nature, gdzie Behe mógłby znaleźć dużą ilość teoretycznych i eksperymentalnych rozpraw dotyczących pochodzenia życia. Znalazłby tam na przykład rozprawy traktujące o tym, w jaki sposób amfifile, pochodne chondrytów węglowych, mogą dawać początek błonopodobnym strukturom, jak micelle i pęcherzyki; jak takie struktury autokatalitycznie składają się i replikują; oraz w jaki sposób aromatyczne węglowodory policykliczne, znajdowane również w meteorytach, mogą się osadzać i przy

\footnotetext{
${ }^{4}$ H.J. Morowitz, B. Heinz and D.W. Deamer, „Biogenesis and Evolutionary Process”, Journal of Molecular Evolution 1991, vol. 33, s. 207-208.
} 
stosowywać do warunków panujących w dwuwarstwowych błonach amfifilowych tak, że może następować przemieszczanie się protonów - ważny mechanizm przenoszący energię w komórce. ${ }^{5}$ Pominięto też ważne prace podsumowujące nowatorskie ujęcia problemu pochodzenia życia, na przykład prace R.J.P. Williamsa i J.J.R. Frausto da Silvy oraz Harolda Morowitza. ${ }^{6}$ Niezależnie od tego, czy Behe uznaje takie prace za istotne, powinien przynajmniej donieść swoim czytelnikom, że one faktycznie istnieją, gdyż mówi on o ich rzekomym nieistnieniu.

Jednej z prób wyjaśnienia pochodzenia życia Behe poświęcił nieco uwagi - chodzi o Origins of Order [Pochodzenie uporządkowania] Stuarta Kauffmana. ${ }^{7}$ Behe argumentuje, że Kauffman może otrzymać samoorganizację w swoich symulacjach komputerowych tylko w specjalnych początkowych i brzegowych warunkach i że do zjawiska organizacji prowadzą tylko pewne rodzaje interakcji pomiędzy składnikami jego modeli. Skoro samoorganizacja nie zachodzi za pomocą całkowicie przypadkowych zdarzeń, lecz wymaga pewnych „skłonności" do oddziaływania, a także pewnego typu doboru, Behe konkluduje, że ujęcie Kauffmana można bezpiecznie odrzucić jako nieistotne dla problemu emergencji systemów żywych. Behe zdaje się w ogóle nie rozumieć istoty pomysłu Kauffmana.

\footnotetext{
${ }^{5}$ D.W. Deamer and R.M. Pashley, „Amphiphilic Components of the Murchison Carbonaceous Chondrite: Surface Properties and Membrane Formation", Origin of Life and Evolution of the Biosphere 1989, vol. 19, s. 21-38; P.A. Bachmann, P.L. Luisi and J. LANG, „Autocatalytic Self-Replicating Micells as Models for Prebiotic Structures", Nature 1992, vol. 357, s. 5779; D.W. Deamer and E. Harang, „Light-Dependent pH Gradients Are Generated in Liposomes Containing Ferrocyanide", BioSystems 1990, vol. 24, s. 14.

${ }^{6}$ R.J.P. Williams and J.J.R. Frausto da Silva, The Natural Selection of the Chemical Elements, Oxford University Press, Oxford 1996; H.J. Morowitz, Beginnings of Cellular Life: Metabolism Recapitulates Biogenesis, Yale University Press, New Haven, Conn. 1992.

${ }^{7}$ S.A. KaUfFMAn, Origins of Order: Self-Organization and Selection in Evolution, Oxford University Press, New York 1993; BeHE, Darwin's Black Box..., s. 155-156, 178-179, 189-192.
} 
Choć modele Kauffmana są proste, ich niezwykłość przejawia się w tym, że obejmują one zakres dynamicznego zachowania się systemów biologicznych. ${ }^{8}$ Oczywiście, programista musi wbudowywać ograniczenia. Pytanie tylko, czy owe ograniczenia są rozsądne, przynajmniej przez analogię odzwierciedlające kategorie lokalnej interakcji między składnikami, którym daleko do stanu równowagi. Oznacza to - w stopniu, w jakim modele Kauffmana odzwierciedlają wpływ wbudowanych skłonności molekularnych właściwości i interakcji, jak również przepływ energii oraz entropię $\mathrm{w}$ prawdziwych układach fizycznych i biologicznych - że można je badać przy pomocy symulacji w celu uzyskania wglądu w możliwe wielkoskalowe zdarzenia, zachodzące w systemach naturalnych. Owe skłonności występują w przyrodzie; aby stworzyć model ich istnienia, programista musi wprowadzić pewien rodzaj podobnego ograniczenia. ${ }^{9}$ Żądanie, by samoorganizacja wyłoniła się z całkowicie ergodycznego układu, sprowadza się do zaprzeczenia tego, że w rzeczywistym świecie istnieją skłonności oraz warunki początkowe i brzegowe.

Stwierdzenie ich istnienia nie wyjaśnia, dlaczego w przyrodzie istnieją takie skłonności do oddziaływania i samoorganizacji. Biorąc pod uwagę ustawienia parametrów zarówno $\mathrm{w}$ przyrodzie, jak i $\mathrm{w}$ symulacjach, można sformułować interesujący argument na rzecz hipotezy projektu. Jednak badaczy emergencji życia nie interesuje źródło skłonności, lecz konsekwencje ich istnienia.

Argumentowałem, że modele Kauffmana zapewniają wgląd w to, co może mieć znaczenie dla emergencji życia. ${ }^{10}$ Jego pojęcie przestrzeni fazowej sekwencji białkowych i sposób jego badania, w połączeniu z pojęciem przestrzeni działania katalitycznego, dostarcza-

\footnotetext{
${ }^{8}$ D.J. Depew and B.H. Weber, Darwinism Evolving: Systems Dynamics and the Genealogy of Natural Selection, MIT Press, Cambridge 1995.

${ }^{9}$ R.E. Ulanowicz, ,The Propensities of Evolving Systems”, w: E.L. Khalil and K.E. Bounding, Evolution, Order and Complexity, Routledge, London 1996, s. 217-233.

${ }^{10}$ B.H. Weber, „Origins of Order in Dynamical Models”, Biology and Philosophy 1998, vol. 13 , s. $133-144$.
} 
ją ujęcia, dzięki któremu można rozpatrzyć, jak zespoły początkowo przypadkowych sekwencji mogły z biegiem czasu zostać wyselekcjonowane przez dobór chemiczny w celu uzyskania większej wydajności katalitycznej i termodynamicznej, by łatwiej sprostać różnym zadaniom katalitycznym. Inną kluczową kwestią jest zamknięcie katalityczne, przy pomocy którego zespoły polimerów autokatalitycznych o dostatecznej złożoności mogą przechodzić „fazę tranzycji” w zamknięty, emergentny ,protometabolizm”.

Przy stosownych warunkach początkowych i brzegowych przepływu oraz gradientów energii lub materii fizyczne i chemiczne systemy naturalne spontanicznie się samoorganizują, generując makroskopowo uorganizowaną strukturę pod wpływem termodynamicznych kierunków rozproszenia, któremu daleko do stanu równowagi. Ujęcia opisujące takie zjawiska rozszerzono na układy biologiczne, łącznie $\mathrm{z}$ problemem emergencji życia. ${ }^{11}$ Własności oraz skłonności atomowe i molekularne mogły oddziaływać ze sobą pod wpływem termodynamicznych ograniczeń wczesnego środowiska ziemskiego, współdziałając $\mathrm{z}$ doborem fizycznym $\mathrm{i}$ chemicznym w tworzeniu bardziej złożonych zjawisk emergencji. Oznacza to, że przewidziane przez Kauffmana reakcje chemiczne mogły zachodzić w protokomórce i że życie oraz jego elementy składowe wyłoniły się i - jak sugerują symulacje Kauffmana - stały się bardziej wyraziste jako całość niż jako pojawiające się po kolei.

Takie ujęcie emergencji systemów żywych sugeruje, że dobór biologiczny (dobór naturalny) przystosowania reprodukcyjnego w postaci życia i informacji genetycznej - jako zjawisko - powstał z wcześniej działającego doboru fizycznego trwałych elementów składowych i doboru chemicznego elementów wydajnych energetycznie i katalitycznie. Widać stąd, że są różne rodzaje doboru, które same są rezultatem emergencji i które mogą oddziaływać z samoorganizacyj-

\footnotetext{
${ }^{11}$ B.H. Weber, „Emergence of Life and Biological Selection from the Perspective of Complex Systems Dynamics", w: G. van de Vijver, S.S. Salthe and M. Delpos (eds.), Evolutionary Systems, Kluwer, Dordrecht 1998.
} 
nymi własnościami systemów różnego typu, występujących na różnych poziomach. ${ }^{12}$ Dobór nie musi robić wszystkiego czy tylko stopniowo, ponieważ w generowaniu porządku i organizacji może wspomagać go samoorganizacja. Jest jasne, że samoorganizacja również nie musi robić wszystkiego sama. Żadna racjonalna osoba nie powinna oczekiwać, że sam przypadek mógłby utworzyć porządek $\mathrm{z}$ chaosu. Aby dać dobre wyjaśnienia zjawiska emergencji, należy brać pod uwagę wszystkie te trzy czynniki jako do pewnego stopnia w specyficznych przypadkach działające razem. Zastosowanie „dynamiki systemów złożonych" do problemów biologicznych nadal znajduje się w stadium niemowlęctwa. Niemniej jednak ważne jest, że zawiązała się wspólnota badawcza, do której zaliczają się pewni „pełnoprawni” darwiniści, podejmująca próbę rozwiązania problemów związanych ze zjawiskiem emergencji w ogóle, a zwłaszcza w układach biologicznych, wyjaśniając jednocześnie to, co Behe uważa za „nieredukowalnie złożone".

Aktualna literatura naukowa osłabia więc twierdzenie Behe'ego o nieredukowalnej złożoności systemów biochemicznych. Pozostaje jednak wyjaśnić jeszcze jedno ważne zagadnienie. Zastosowanie dynamiki układów złożonych może pokazać, jak rozumieć emergencję tego rodzaju funkcjonalnej złożoności, którym interesuje się Behe. Charakterystyczną cechą nauk o życiu, w połączeniu z ludzkim punktem widzenia, jest ich niekompletność, która zmniejsza się w miarę ich rozwoju. Żądanie natychmiastowego i zupełnego wyjaśnienia, które można spełnić tylko poprzez odwołanie się do „Boskiej interwencji”, nie stworzy nowego paradygmatu, tak samo jak byłoby w przypadku zaprzestania badań nad problemem emergencji. Sam ten pomysł jest niespójny z fundamentami nauk przyrodniczych.

Sposób przedstawiania przez Behe'ego pułapki na myszy - analogii układów biologicznych, odpowiednika zegara Paleya - sugeruje, że

\footnotetext{
${ }^{12}$ B.H. Weber and D.J. Depew, „Natural Selection and Self-Organization: Dynamical Models as Clues to a New Evolutionary Synthesis", Biology and Philosophy 1996, vol. 11, s. 33-65.
} 
organizmy i ich elementy składowe albo sa artefaktami, czy sa analogiczne do artefaktów, albo częściowo mają charakter artefaktów. Ale organizmy odróżniano od artefaktów, od kiedy Arystoteles pisał o wielkiej różnicy między domem, który miał projektanta i budowniczego, a zwierzęciem, będącym wytworem cyklu wzrostu, rozwoju i reprodukcji, którego części można zdefiniować, sprowadzić do istnienia i które faktycznie mogą istnieć tylko w relacji do całości. Organizmy nie są złożeniami bliżej nieokreślonych elementów.

Behe przyznaje, że artefakty stanowią słabą analogię do organizmów ze względu na fakt, iż artefakty i organizmy mają odmienne warunki dekompozycji. Twierdzi on jednak, że to, co w artefaktach jest dobrą analogią do organizmów, to nieredukowalna złożoność. Behe powiada, że musimy wnioskować do najlepszego argumentu. Twierdzi on, że są tylko dwa możliwe sposoby wyjaśniania nieredukowalnej złożoności. Jeśli nie można wyjaśnić jej doborem, to wnioskuje się o inteligentnym projekcie. Domniemaną trudność nieredukowalnej złożoności można jednak $\mathrm{z}$ łatwością pochopnie rozszerzyć na układy naturalne. Co więcej - fakt, że organizmy powstają w procesie rozwojowym, w którym elementy potrzebne w kolejnych etapach tworzą się podczas etapów wcześniejszych, sugeruje, że przypadek, dobór i samoorganizacja mogą współdziałać. Każda próba zrozumienia zjawiska emergencji złożoności musi odnosić się do rzeczywistości rozwojowej.

Obecnie na rozmaite sposoby bada się możliwość całkowitej integracji biologii rozwojowej i teorii ewolucji. Behe w ogóle o tym nie wspomina. Gdy głębiej zrozumiemy zjawiska rozwoju i ewolucji, dowiemy się prawdopodobnie, że rozwijające się organizmy różnią się od artefaktów tak bardzo, jak to tylko możliwe. A więc kwestia nieodłączności struktury organicznej od projektu, oparta na analogii do artefaktów, stanie się nieistotna. Zrozumiemy, że właściwy sposób badania złożoności biologicznej polega na rozpatrywaniu jej od strony jej emergencji, trajektorii rozwojowych i rodowodów ewolucyjnych. Może być również tak - gdy nauki przyrodnicze lepiej zaznajomią się z pojęciami złożoności - że będziemy zmuszeni uznać, iż nawet nasza 
wcześniejsza nauka jest reliktem minionego kryptoteologicznego wieku - i że będziemy musieli znaleźć bogatszą i subtelniejszą teologię, jak również subtelniejszą naukę.

Bruce H. Weber 